\title{
Increased plasma leptin attenuates adaptive metabolism in early lactating dairy cows
}

\section{Richard A Ehrhardt', Andreas Foskolos², Sarah L Giesy3, Stephanie R Wesolowski, \\ Christopher S Krumm³, W Ronald Butler³, Susan M Quirk3, Matthew R Waldron³ and Yves R Boisclair ${ }^{3}$}

1Departments of Animal Science and Large Animal Clinical Sciences, Michigan State University, East Lansing, Michigan, USA

2Institute of Biological, Environmental and Rural Sciences, Aberystwyth University, Aberystwyth, UK 3Department of Animal Science, Cornell University, Ithaca, New York, USA

${ }^{4}$ University of Colorado School of Medicine, Aurora, Colorado, USA

Correspondence should be addressed to $\mathrm{Y}$ Boisclair Email yrb1@cornell.edu

\begin{abstract}
Mammals meet the increased nutritional demands of lactation through a combination of increased feed intake and a collection of adaptations known as adaptive metabolism (e.g., glucose sparing via insulin resistance, mobilization of endogenous reserves, and increased metabolic efficiency via reduced thyroid hormones). In the modern dairy cow, adaptive metabolism predominates over increased feed intake at the onset of lactation and develops concurrently with a reduction in plasma leptin. To address the role of leptin in the adaptive metabolism of early lactation, we asked which adaptations could be countered by a constant 96-h intravenous infusion of human leptin (hLeptin) starting on day 8 of lactation. Compared to saline infusion (Control), hLeptin did not alter energy intake or milk energy output but caused a modest increase in body weight loss. hLeptin reduced plasma glucose by $9 \%$ and hepatic glycogen content by $73 \%$, and these effects were associated with a $17 \%$ increase in glucose disposal during an insulin tolerance test. hLeptin attenuated the accumulation of triglyceride in the liver by $28 \%$ in the absence of effects on plasma levels of the anti-lipolytic hormone insulin or plasma levels of free fatty acids, a marker of lipid mobilization from adipose tissue. Finally, hLeptin increased the plasma concentrations of $\mathrm{T}_{4}$ and $\mathrm{T}_{3}$ by nearly $50 \%$ without affecting other neurally regulated hormones (i.e., cortisol and luteinizing hormone (LH)). Overall these data implicate the periparturient reduction in plasma leptin as one of the signals promoting conservation of glucose and energy at the onset of lactation in the energy-deficient dairy cow.
\end{abstract}

\section{Introduction}

In most mammals, the nutrient demands of lactation are met by a combination of increased voluntary feed intake and adaptive metabolism (Vernon et al. 2002).
Adaptive metabolism refers to processes preserving metabolic homeostasis during periods of energy insufficiency and includes mobilization of endogenous 
reserves, tissue-specific insulin resistance, and improved metabolic efficiency (Bell 1995, Vernon et al. 2002, Boisclair et al. 2006). The relative importance of increased feed intake vs adaptive metabolism in support of lactation varies across species. This can be illustrated by comparing the mouse and the modern dairy cow, two species with similar milk energy output when expressed on a metabolic body weight basis (Prentice \& Prentice 1988). After parturition, the lactating mouse meets a gradual increase in mammary nutrient demand nearly entirely by a matching increase in feed intake (Johnson et al. 2001, Vernon et al. 2002). By contrast, the modern dairy cow reaches near peak milk production within days of parturition in the absence of a compensating increase in voluntary appetite (Bell 1995, Block et al. 2001, Reist et al. 2003). The energy deficit that follows can reach $30 \%$ of total energy requirements over the first month of lactation, necessitating sustained reliance on adaptive metabolism (Bell 1995, Vernon et al. 2002). Accordingly, the modern dairy cow provides an opportunity to understand factors triggering adaptive metabolism in the context of lactation.

Adaptive metabolism is hormonally regulated as illustrated by adaptations triggered in early lactating dairy cows by interactions among insulin, growth hormone (GH), and insulin-like growth factor (IGF)1. Specifically, the hypoinsulinemia of early lactation causes loss of the liver GH receptor and reduced hepatic IGF1 production (Rhoads et al. 2004, Wook Kim et al. 2004). As a consequence of the reduced IGF1 feedback, plasma GH increases, promoting insulin resistance and partitioning of available glucose to the mammary gland in which uptake is insulin independent (Bell 1995, Boisclair et al. 2006). More recently, we and others have reported that plasma leptin drops by $30-50 \%$ during the days surrounding parturition (Block et al. 2001, Reist et al. 2003, Janovick et al. 2011). This rapid reduction in plasma leptin was caused by the onset of negative energy balance rather than depletion of adipose tissue or loss of the placenta (Block et al. 2001, Boisclair et al. 2006). A similar reduction in plasma leptin in other physiological contexts promotes adaptive metabolism (Rosenbaum \& Leibel 2014, Park \& Ahima 2015), but whether it plays this role in the energy-deficient, early lactating dairy cow remains unknown. To answer this question, we reversed the leptin deficit of early lactating by chronic intravenous infusion. Leptin infusion did not impact voluntary energy intake or milk production but attenuated adaptations responsible for glucose and energy conservation in early lactation.

\section{Materials and methods}

\section{Animals and design}

All experimental procedures were performed at Cornell University (Ithaca, NY, USA) and approved by the Institutional Animal Care and Use Committee. Two experiments were performed sequentially with ten mature Holstein dairy cows (parity $\geq 2$ ). The first experiment described metabolic changes occurring during the transition from late pregnancy (LP) to early lactation (EL) by studying cows with a common set of procedures between days $-32 \pm 2.0$ and $-29 \pm 2.0$ and between days 6 and 8 (relative to parturition on day 0 ). Cows were weighed and then fitted with bilateral jugular vein catheters on days -32 and 6 , administered an insulin tolerance test on days -31 and 7 , and sampled frequently on days -29 and 8 (every $10 \mathrm{~min}$ for $8 \mathrm{~h}$ ). The frequent blood samples served for the analysis of plasma variables on an hourly basis (glucose, free fatty acids, leptin, insulin, IGF1, $\mathrm{T}_{3}$, and $\mathrm{T}_{4}$ ) or every $10 \mathrm{~min}$ (GH and luteinizing hormone (LH)). Finally, biopsies of the liver were obtained following frequent blood sampling. Cows were fed total mixed rations formulated for each physiological stage (i.e., 1.5 Mcal net energy of lactation $\left(\mathrm{NE}_{\mathrm{L}}\right)$ and $140 \mathrm{~g}$ of crude protein $(\mathrm{CP})$ per kg dry matter (DM) in LP and $1.5 \mathrm{Mcal} \mathrm{NE}_{\mathrm{L}}$ and $180 \mathrm{~g}$ of $\mathrm{CP}$ per $\mathrm{kg} \mathrm{DM}$ in EL). Rations were offered in unlimited amounts, once daily in LP and as meals served every $4 \mathrm{~h}$ in EL. After parturition, cows were milked twice daily at 6:00 and 18:00 h.

The second experiment assessed the effect of leptin administration on the metabolic adaptations of EL. Starting after the 18:00 h milking on day 8 of EL, cows received an intravenous infusion of either saline solution (Control) or recombinant human leptin (hLeptin, Eli Lilly) for $96 \mathrm{~h}$. hLeptin was dissolved in saline solution with individual cow plasma as a carrier $(2.5 \% \mathrm{vol} / \mathrm{vol})$ and infused at the rate of $61 \mu \mathrm{g} / \mathrm{kg}$ body weight/day. Both saline and hLeptin solutions were delivered as a $6.25 \mathrm{~mL} / \mathrm{h}$ infusion using a syringe pump. Frequent blood samples were obtained for the first $6 \mathrm{~h}$ and every $4 \mathrm{~h}$ thereafter. Other experimental procedures included an insulin tolerance test on day 11 , frequent blood sampling on day 12 (every $10 \mathrm{~min}$ for $8 \mathrm{~h}$ ), and biopsies of the liver before discontinuing infusions at 18:00 h on day 12 . Cows were fed and milked exactly as described in the EL phase of the first experiment.

For both experiments, individual net energy balance was calculated as the difference between energy intake and energy expenditure (maintenance and pregnancy in LP and maintenance and milk energy in EL) exactly as described by Block and coworkers (Block et al. 2001).

Published by Bioscientifica Ltd 
Predictive equations were used to estimate the energy content of feed and milk from chemical composition and the maintenance energy requirement from body weight (National Research Council 2001).

\section{Analysis of metabolites and hormones}

Methods previously validated in our laboratory were used to analyze triglyceride and glycogen content in the liver and plasma glucose and free fatty acids (Leury et al. 2003, Rhoads et al. 2004). The insulin tolerance test was performed by intravenous administration of an insulin bolus $(1.0 \mu \mathrm{g} / \mathrm{kg}$ body weight bovine insulin, Sigma). Sampling frequency and calculation of the glucose response area were performed exactly as described by Sechen et al. (1990). Inter- and intra-assay coefficients of variation for all metabolic assays were $<7$ and $<5 \%$, respectively.

Plasma leptin was measured with double-antibody RIAs capable of detecting only bovine (Ehrhardt et al. 2000) or hLeptin (Linco Research, Inc.). The fractional rate of hLeptin elimination in the vascular compartment was estimated with the relationship $C=b\left(1-e^{-k t}\right)$, where $C$ is the plasma concentration of hLeptin at time $t, b$ is the hLeptin concentration at plateau (average plasma concentration between 24 and $96 \mathrm{~h}$ of infusion), and $\mathrm{k}$ is the rate constant for elimination (Shipley \& Clark 1972). The half-life of hLeptin was then calculated with the relation: half-life $=\ln 2 / \mathrm{k}$.

Solid-phase RIAs were used to measure total $\mathrm{T}_{3}$ and $\mathrm{T}_{4}$ (Diasorin, Stillwater, MN, USA) and cortisol (Siemens). Plasma insulin, IGF1, GH, and LH were measured using double-antibody RIAs previously validated in cattle (Leury et al. 2003, Rhoads et al. 2004, Butler et al. 2006). Analysis of the pattern of GH and LH secretion was performed on samples collected every $10 \mathrm{~min}$ on days 8 and 12 of lactation. Parameters analyzed were mean plasma concentration, pulse number, and pulse amplitude. Pulses were identified as described by Karsch et al. (1987) and corresponded to increases greater than the assay sensitivity, exceeding the previous value by $>3$ times the standard deviation, and followed by steady decline consistent with the half-life. Inter- and intra-assay coefficients of variation for all hormone assays were $<6$ and $<8 \%$, respectively.

\section{In vitro bioactivity of hLeptin}

hLeptin activity was measured using a bioassay consisting of human embryonic kidney 293 (HEK293) cells transfected with plasmid $\mathrm{bOBR}_{\mathrm{b}}$ expressing the full-length bovine leptin receptor and luciferase plasmid p4xM67-TKLuc containing four tandem repeats of the STAT3-binding site in front of the minimal thymidine kinase promoter (Besser et al. 1999). Construction of plasmid $\mathrm{bOBR}_{\mathrm{b}}$ involved reverse transcription of total RNA from bovine hypothalamus followed by high fidelity amplification of the leptin receptor cDNA using procedures validated in our laboratory (Boisclair et al. 1996). The resulting cDNA was subcloned into the expression plasmid pcDNA4/myc-His and shown by sequencing to encode a protein with an amino acid sequence identical to the full-length bLeptin receptor (RefSeq NM_001012285.2).

Transfection and luciferase assays were performed as previously described (Boisclair et al. 1993). In brief, HEK293 cells were grown to $50 \%$ confluence in six well plates in minimal Eagle's medium (Life Technologies) supplemented with $10 \%$ fetal calf serum. Each well was transfected overnight with $2.5 \mu \mathrm{g}$ each of $\mathrm{bOBR}_{\mathrm{b}}$ and p4xM67-TK-Luc using the calcium phosphate precipitation. After a $24 \mathrm{~h}$ recovery in serum free media, cells were stimulated with either hLeptin, human leptin obtained from the National Hormone and Peptide Program (hLeptin-N; Torrance, CA, USA) or bovine Leptin (bLeptin) (Protein Laboratories, Rehovot, Israel). Luciferase activity was assayed $6 \mathrm{~h}$ later using the Dual Luciferase reporter system (Promega) and normalized to the protein content of lysates.

\section{Gene expression analysis}

Total RNA was purified using RNeasy minicolumns and on-column ribonuclease-free deoxyribonuclease treatment (Qiagen Inc.). Integrity of RNA was determined using the RNA Nano Lab chip kit and Bioanalyzer (Agilent). Reverse transcription and SYBR Green real-time PCR assays were performed exactly as described previously (Giesy et al. 2012). Primers are listed in Supplementary Table 1 , see section on supplementary data given at the end of this article. mRNA data were analyzed using a relative standard curve based on serial two-fold dilutions of pooled cDNA prepared from the liver. Unknown sample expression was determined from the standard curve, adjusted for expression of the invariant control gene $B 2 \mathrm{M}$, and reported as a fold difference.

\section{Western blot analysis}

Plasma samples $(2.5 \mu \mathrm{L}$ of a $1: 6$ dilution) were mixed with equal volumes of $2 \times$ Laemmli buffer containing dithiothreitol and mercaptoethanol and boiled for $10 \mathrm{~min}$.

Published by Bioscientifica Ltd 
They were electrophoresed on 13\% SDS-PAGE gels and electroblotted onto nitrocellulose membranes (Protran, Schleicher \& Schuell Bioscience, Keene, NH, USA). The membranes were blocked in Tris-buffered saline with Tween-20 (TBST; $0.05 \mathrm{M}$ Tris, pH 7.4, $0.2 \mathrm{M} \mathrm{NaCl}, 0.1 \%$ Tween-20) containing 3\% w/v nonfat dried skim milk (NFM) for $1 \mathrm{~h}$ at room temperature and incubated with 1:1000 dilution of bovine insulin-like growth factorbinding protein 2 (IGFBP2) antiserum (\#06-107, Millipore) in the blocking buffer for $2 \mathrm{~h}$ at room temperature. After washes in TBST, membranes were incubated with 1:20,000 IRDye 800 goat anti-rabbit secondary antibody (LI-COR Biotechnology, Lincoln, NE, USA) in TBST with 3\% NFM for $1 \mathrm{~h}$ at room temperature. Signals were quantified with the LI-COR Odyssey infrared imaging system (LI-COR Biosciences, Lincoln, NE, USA) using the 800-nm channel.

\section{Statistical analysis}

Data were analyzed by the MIXED procedure of SAS (SAS Institute, Raleigh, NC, USA). Data obtained during the transition period were analyzed with a model accounting for physiological stage (LP or EL) as a fixed effect and cow as a random effect. For the infusion study, data collected over time were analyzed with a model accounting for treatment (Control or hLeptin), time and their interaction as fixed effects and cow as a random effect. All other variables were analyzed with a model accounting for treatment (Control or hLeptin) as fixed effects and cow as a random effect. A covariate corresponding to data collected prior to infusion (i.e., between days 6 and 8 of EL) was included in the statistical models used for the infusion period only when significant. The level of significance was set at $P<0.05$ for main effects and $P<0.10$ for interactions.

\section{Results}

\section{Changes in energy-related variables during the transition from late pregnancy to early lactation}

Cows were studied in LP between days -32 and -29 and again in EL between days 6 and 8. Energy balance shifted from a surplus of $12 \mathrm{Mcal}$ in LP to a deficit of $15 \mathrm{Mcal}$ in EL (Table $1 ; P<0.01$ ). This shift reflected increased energy output in the form of milk in the absence of a compensatory increase in energy intake. The nutritional deficit of EL was associated with reductions of $18 \%$ in plasma glucose, $62 \%$ in liver glycogen, and $25 \%$ in the
Table 1 Effect of the transition from LP to EL on whole-animal and metabolic variables.

\begin{tabular}{|c|c|c|c|c|}
\hline & \multicolumn{2}{|c|}{$\begin{array}{l}\text { Physiological } \\
\text { state }^{a}\end{array}$} & \multirow[b]{2}{*}{ S.E.M. } & \multirow[b]{2}{*}{$P$-valueb } \\
\hline & LP & EL & & \\
\hline \multicolumn{5}{|l|}{ Whole animal } \\
\hline Body weight, kg & 648 & 575 & 13 & $<0.01$ \\
\hline Dry matter intake, kg/day & 15.6 & 15.5 & 0.8 & NS \\
\hline Energy intake, Mcal/day & 22.4 & 24.2 & 1.2 & NS \\
\hline Energy balance, Mcal/day & 12.1 & -15.2 & 1.5 & $<0.01$ \\
\hline $\begin{array}{l}\text { Glucose response areac, } \\
\mathrm{mg} \text { glucose } / \mathrm{dL} \times \min \end{array}$ & 1182 & 878 & 55 & $<0.01$ \\
\hline \multicolumn{5}{|l|}{ Plasma variables } \\
\hline Glucose, mg/dL & 66 & 54 & 1 & $<0.01$ \\
\hline Free fatty acids, $\mu \mathrm{M}$ & 108 & 386 & 43 & $<0.01$ \\
\hline Insulin, ng/mL & 0.26 & 0.08 & 0.01 & $<0.01$ \\
\hline IGF1, ng/mL & 193 & 56 & 11 & $<0.01$ \\
\hline $\mathrm{T}_{4}, \mathrm{ng} / \mathrm{mL}$ & 5.13 & 1.75 & 0.23 & $<0.01$ \\
\hline $\mathrm{T}_{3}, \mathrm{ng} / \mathrm{mL}$ & 1.58 & 0.95 & 0.06 & $<0.01$ \\
\hline Leptin, ng/mL & 3.1 & 2.3 & 0.1 & $<0.01$ \\
\hline Cortisol, ng/mL & 0.30 & 0.37 & 0.05 & NS \\
\hline \multicolumn{5}{|l|}{ Liver } \\
\hline $\begin{array}{l}\text { Triglycerides, \% wet } \\
\text { weight }\end{array}$ & 1.4 & 7.2 & 1.0 & $<0.01$ \\
\hline Glycogen, $\%$ wet weight & 2.72 & 0.85 & 0.19 & $<0.0001$ \\
\hline
\end{tabular}

aDairy cows $(n=10)$ were studied over a 4-day period in late pregnancy (LP) (day -32 to -29 relative to parturition on day 0 ) and again over a 3-day period in early lactation (EL) (days 6-8); bType I error probability for physiological state; NS, nonsignificant; 'Glucose response area during the insulin tolerance test calculated between time 0 (time of insulin bolus) and $180 \mathrm{~min}$ and corrected for the difference in baseline glucose concentration.

glucose response area during the insulin tolerance test $(P<0.01$ or less). By contrast, the plasma concentration of free fatty acids and the liver triglyceride content were, respectively, 3.6- and 6-fold higher in EL than in LP $(P<0.01)$. These data illustrate the precarious glucose economy of EL and adaptations preserving its availability for mammary use (e.g., attenuation of insulin-dependent use and increased reliance on mobilized lipids).

The transition from LP to EL led to reductions in plasma insulin, IGF1, thyroid hormones, and leptin $(P<0.01)$. Reduced plasma concentrations of the first three of these hormones have been shown to drive adaptive metabolism in early lactating dairy cows (Bauman \& Vernon 1993, Bell 1995, Boisclair et al. 2006), but the contribution of reduced plasma leptin remains unknown.

\section{Effect of increased plasma leptin on the whole animal energy budget in early lactation}

To address the role of leptin in EL, we sought to reverse its reduction with exogenous administration of hLeptin.

Published by Bioscientifica Ltd. 

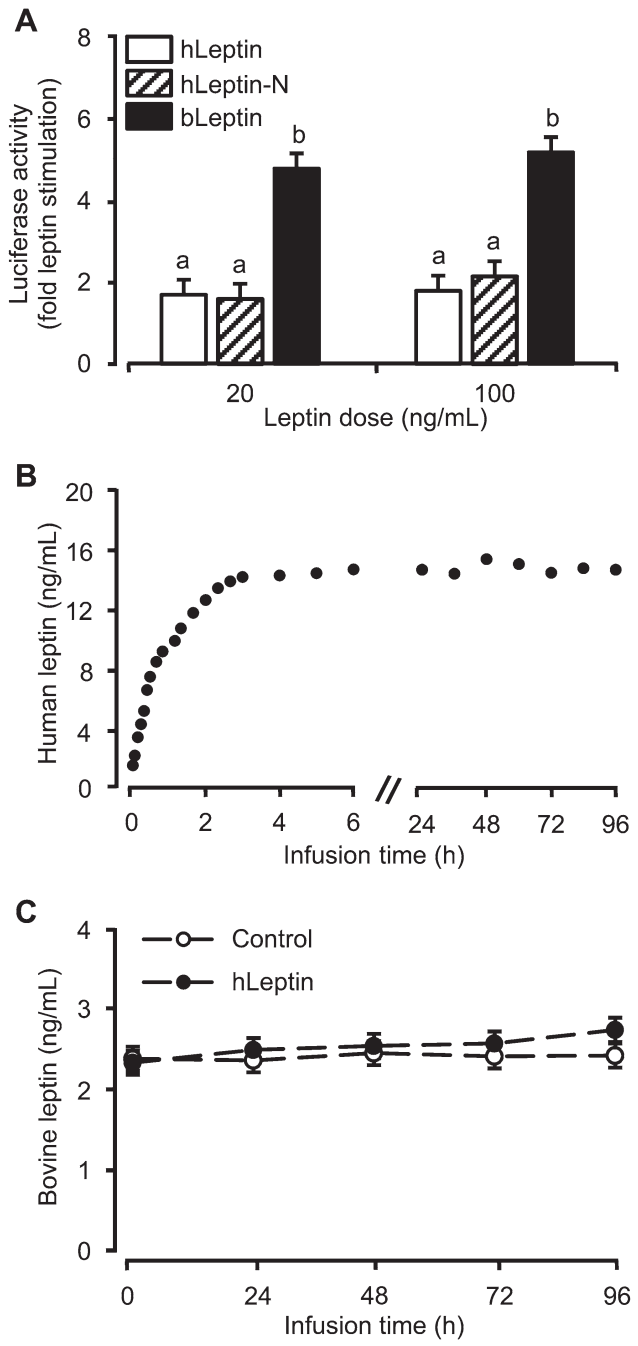

Figure 1

Bioactivity and plasma profile of human leptin in cattle. (A) HEK293 cells were transfected in duplicate with plasmid $\mathrm{bOBR}_{\mathrm{b}}$ encoding the full-length bLeptin receptor and the STAT3 luciferase reporter plasmid p4xM67-TK-Luc. Transfected cells were incubated for $24 \mathrm{~h}$ in serum-free media or in serum-free media supplemented with 20 or $100 \mathrm{ng} / \mathrm{mL}$ of human leptin (hLeptin) obtained from either Eli Lilly (hLeptin) or from the National Hormone and Peptide Program (hLeptin-N) or bovine leptin (bLeptin). Firefly luciferase was measured in cell extracts, corrected for protein concentration, and expressed as a fold of luciferase expression in untreated transfected cells. Each bar represents the mean \pm S.E.M. of two replicates. For each concentration, bars with different letters differ at $P<0.05$. Similar results were obtained in a second experiment. (B) The plasma concentration of human leptin in dairy cows receiving a constant intravenous infusion of recombinant human leptin (hLeptin). The infusion started on day 8 of lactation and lasted for 96 consecutive hours. The plasma concentration was measured with an human leptin RIA devoid of cross-reactivity toward bovine leptin. Each point represents the mean of hLeptin concentration $(n=5)$ and has a pooled standard error of $1.0 \mathrm{ng} / \mathrm{mL}$. (C) The plasma concentration of bovine leptin was measured in dairy cows receiving a constant intravenous infusion of saline (Control) or recombinant hLeptin. The infusion started on day 8 of lactation and lasted for 96 consecutive hours. The plasma concentration was measured with a bovine leptin RIA devoid of crossreactivity toward human leptin. Each point represents the mean \pm s.E.M. of the plasma concentration of bovine leptin $(n=5)$.
As a first step, the ability of hLeptin to activate the bLeptin receptor was estimated in HEK293 cells cotransfected with plasmids encoding the full-length bLeptin receptor and a STAT3-dependent luciferase gene. Cells were treated for $24 \mathrm{~h}$ with 0,20 , or $100 \mathrm{ng} / \mathrm{mL}$ of either hLeptin or bLeptin, and luciferase activity was measured (Fig. 1A). At the $20 \mathrm{ng} / \mathrm{mL}$ dose, hLeptin stimulated the luciferase activity 1.9-fold, but less than the 5 -fold activation obtained with bLeptin $(P<0.05)$; hLeptin-N, a human leptin produced by a different supplier, gave identical results. No further stimulation was seen with any of these hormones when used at the $100 \mathrm{ng} / \mathrm{mL}$ dose. These in vitro data show that human leptin activates the bLeptin receptor but with less potency than its bovine counterpart.

Next, cows were assigned to receive on day 8 of lactation a constant intravenous infusion of saline (Control) or hLeptin for $96 \mathrm{~h}$. In the hLeptin group, human leptin rose to a steady-state concentration of $14.0 \pm 1.0 \mathrm{ng} / \mathrm{mL}$ within $2.3 \mathrm{~h}$ of infusion, consistent with a calculated half-life of $28.0 \pm 5.0 \mathrm{~min}$ in the vascular compartment (Fig. 1B). The plasma concentration of bLeptin was not affected by the hLeptin infusion and did not differ between the Control and hLeptin groups during the infusion period (Fig. 1C).

Voluntary feed intake was recorded over two time intervals during the first $12 \mathrm{~h}$ of infusion and every $12 \mathrm{~h}$ thereafter. Feed intake expressed on an energy basis appeared lower after $4 \mathrm{~h}$ of hLeptin infusion, but this numerical reduction disappeared during the following $8 \mathrm{~h}$ (Fig. 2A) and never reached significance over the next $84 \mathrm{~h}$ (Fig. 2B). The hLeptin infusion did not alter milk secretion over the first $12 \mathrm{~h}$ of infusion or at later times, whether expressed on an energy basis (Fig. 2A and B) or on a volume and composition basis (Supplementary Table 2). Similarly, the energy balance calculated from these primary variables was not affected by the hLeptin treatment when assessed every $12 \mathrm{~h}$ or over the entire infusion period (Fig. 2B and results not shown). Therefore, the periparturient reduction in plasma leptin is not necessary to sustain the appetite and rising milk production of early lactating dairy cows.

\section{Effect of increased plasma leptin on glucose and lipid metabolism in the liver and the whole animal}

Leptin therapy stimulates glucose utilization in various rodent models (Kamohara et al. 1997, Chinookoswong et al. 1999), but whether it is capable of similar actions in the insulin-resistant, early lactating dairy cow is unknown. The hLeptin infusion caused a $9 \%$ reduction in plasma glucose (Table 2, $P<0.01$ ) despite no effects on the hepatic

Published by Bioscientifica Ltd 
A
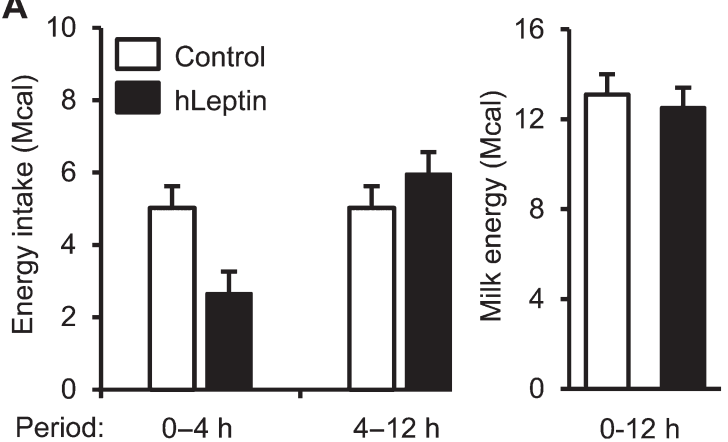

B
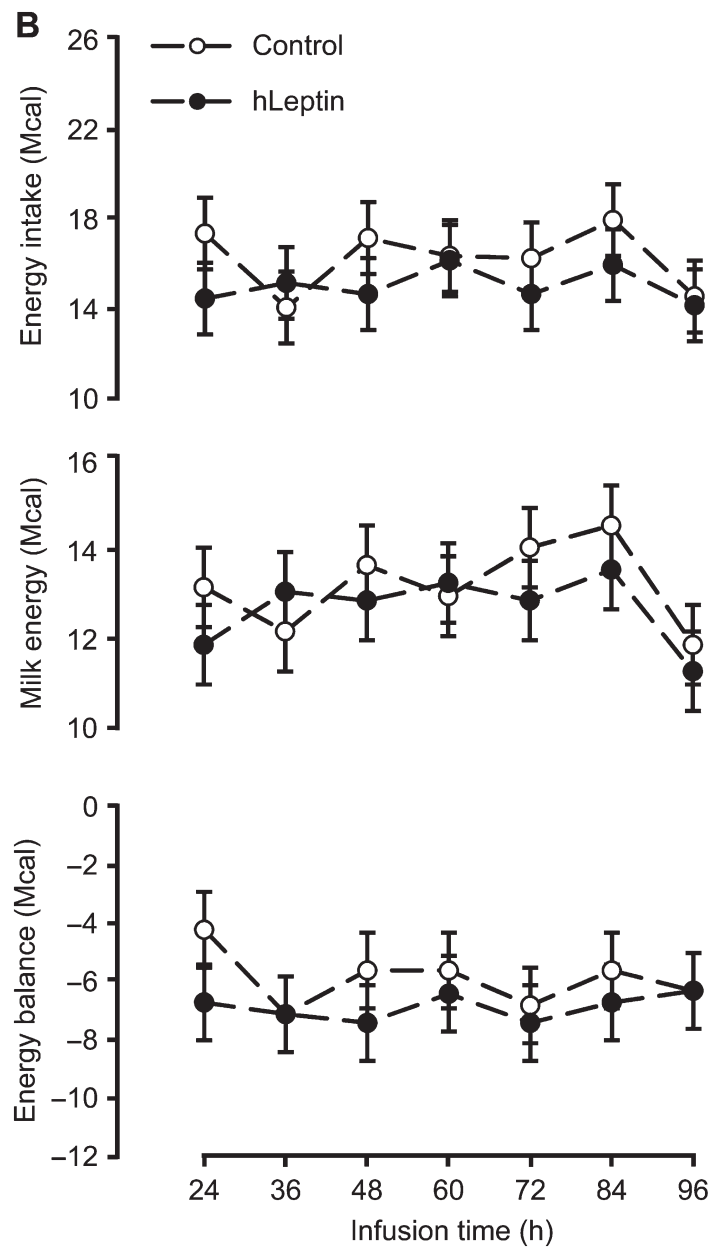

Figure 2

Effect of leptin infusion in early lactation on energy-related variables. Dairy cows received a constant intravenous infusion of either saline (Control) or human leptin (hLeptin) starting on day 8 of lactation and lasting for 96 consecutive hours. (A) Voluntary feed intake and milk output were measured over specific periods during the first day of infusion and expressed on an energy basis. Each bar represents the mean \pm S.E.M. of the indicated variable $(n=5)$. (B) Dry matter intake, milk yield, and milk composition were measured every $12 \mathrm{~h}$. These data were used to calculate energy intake, milk energy output, and net energy balance as described in the "Materials and methods" section. Each data point represents the mean \pm S.E.M. of the indicated variable $(n=5)$
Table 2 Effect of hLeptin infusion in early lactation on plasma variables.

\begin{tabular}{|c|c|c|c|c|}
\hline & \multicolumn{2}{|c|}{ Infusiona } & \multirow[b]{2}{*}{ S.E.M. } & \multirow[b]{2}{*}{ P-value ${ }^{b}$} \\
\hline & Control & hLeptin & & \\
\hline \multicolumn{5}{|l|}{ Plasma metabolites } \\
\hline Glucose, mg/dL & 55.3 & 50.4 & 0.8 & $<0.01$ \\
\hline Free fatty acids, $\mu \mathrm{M}$ & 349 & 408 & 62 & NS \\
\hline \multicolumn{5}{|l|}{ Plasma hormones } \\
\hline Insulin, ng/mL & 0.12 & 0.09 & 0.02 & NS \\
\hline Cortisol, ng/mL & 0.21 & 0.19 & 0.03 & NS \\
\hline $\mathrm{GH}, \mathrm{ng} / \mathrm{mL}$ & 6.0 & 7.6 & 0.5 & 0.04 \\
\hline IGF1, ng/mL & 67 & 53 & 5 & NS \\
\hline $\mathrm{LH}, \mathrm{ng} / \mathrm{mL}$ & 0.60 & 0.61 & 0.06 & NS \\
\hline
\end{tabular}

aDairy cows received continuous intravenous infusion of saline (control) or hLeptin between days 8 and 12 of lactation ( $n=$ five cows per treatment); bType I error probability for physiological state; NS, nonsignificant.

mRNA abundance of the gluconeogenic enzymes PCK1, $P C$, and G6PC (Fig. 3A). The hLeptin infusion increased the glucose response area by $17 \%$ during the insulin tolerance test (Fig. 3B, $P<0.05$ ) in absence of any effects on plasma insulin (Table 2). Finally, hepatic glycogen content was $73 \%$ lower in hLeptin than in control cows (Fig. 3C, $P<0.001)$, suggesting that increased plasma leptin in EL leads to a more precarious glucose economy. This effect reflected a substantial recovery of hepatic glycogen over the treatment period in Control cows (i.e., from $0.85 \%$ wet liver weight on day 8 to $1.53 \%$ on day 12 ) vs continued depression in the hLeptin-treated cows (i.e., $0.46 \%$ wet liver weight on day 12). In leptin-treated mice, enhanced insulin-mediated glucose metabolism has been linked to increased IGFBP2 production (Hedbacker et al. 2010). However, the hLeptin infusion did not increase hepatic IGFBP2 mRNA abundance by the end of treatment (Fig. 3A) or induce a positive change in plasma IGFBP2 over the treatment period (Fig. 3D). Overall, these data suggest that the reduced plasma leptin of EL promotes glucose conservation by attenuating insulin action.

Leptin therapy reduces hepatic lipid accumulation in various rodent models (Levin et al. 1996, Cohen et al. 2002). To determine whether this property is conserved during the pro-steatotic period of EL in dairy cows, liver triglycerides were measured. Hepatic triglyceride content was $28 \%$ lower in the hLeptin than in saline-infused cows (Fig. 4A, $P<0.05$ ). This anti-steatotic effect occurred in the absence of changes in the hepatic expression of genes involved in the transport of free fatty acids across membranes (CD36, FABP1, CPT1A), oxidation (ACADVL, ACOX1), ketogenesis (HMGCS2), or assembly of fatty acids into triglyceride and export as VLDL (SCD, DGAT1, DGAT2, MTTP, P4HB) (Fig. 4B). Moreover, hLeptin did

Published by Bioscientifica Ltd 
A

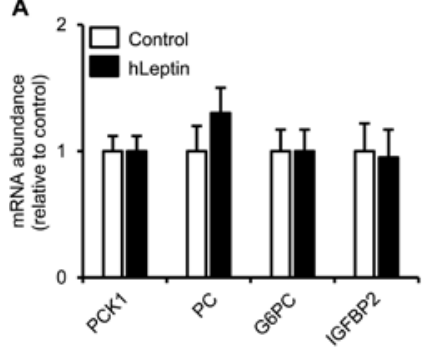

B

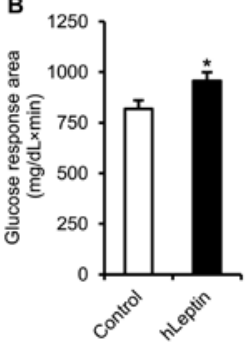

c

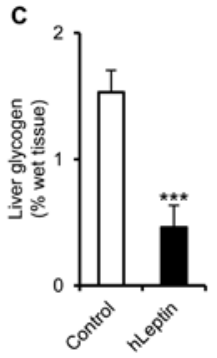

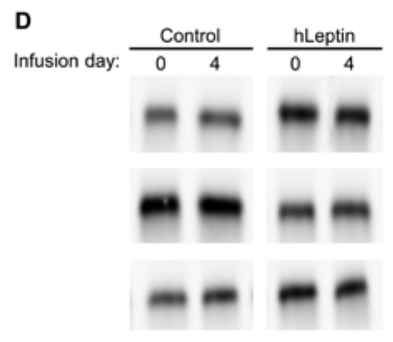

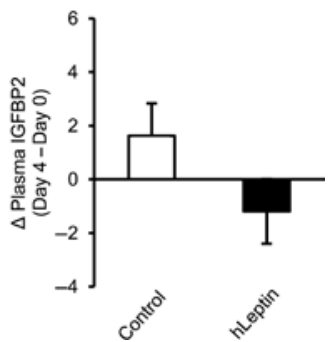

Figure 3

Effect of leptin infusion in early lactation on indicators of glucose metabolism. Dairy cows received a constant intravenous infusion of either saline (Control) or human leptin (hLeptin) starting on day 8 of lactation and lasting for 96 consecutive hours. (A) Total RNA was obtained from liver biopsies taken at the end of infusion and analyzed by quantitative real-time PCR for expression of the indicated genes. For each gene, the expression of the indicated mRNA is relative to control, with each bar representing the mean \pm S.E.M. of five cows. (B) The plasma glucose response area was calculated during the insulin tolerance test performed on day 3 of infusion as described in the "Materials and methods" section. Each bar represents the mean \pm s.E.M. of five cows. ${ }^{*} P<0.05$. (C) Glycogen content was measured on liver biopsies obtained at the end of infusion. Each bar represents the mean \pm S.E.M. of five cows. $* * * P<0.001$. (D) Plasma samples collected immediately before (day 0 ) and at the end of infusion (day 4 ) were analyzed on a single gel for IGFBP2 abundance by Western immunoblotting. Panels on the left show three cows for each treatment. IGFBP2 signals were quantified with the LI-COR Odyssey infrared imaging system, and the change in plasma IGFBP2 abundance over the infusion period ( $\triangle$ Plasma IGFBP2) was calculated for each cow. Bars on the right represent the mean change in plasma IGFBP2 abundance, with each bar representing the mean \pm S.E.M. of five cows.
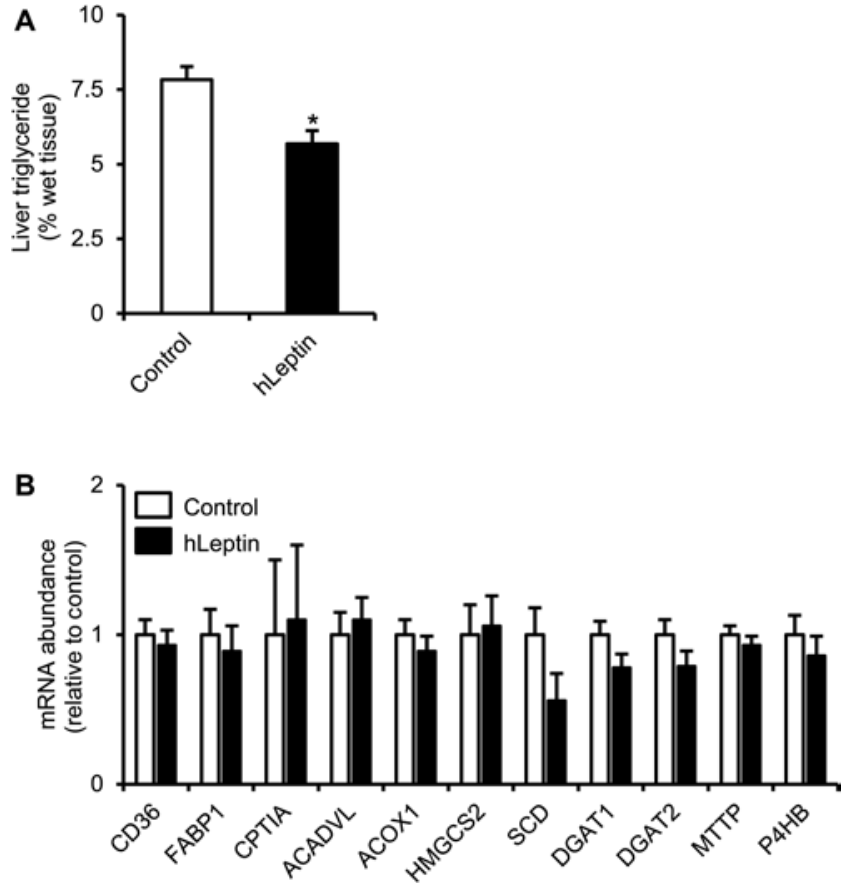

Figure 4

Effect of leptin infusion in early lactation on liver triglyceride levels. Dairy cows received a constant intravenous infusion of either saline (Control) or human leptin (hLeptin) starting on day 8 of lactation and lasting for 96 consecutive hours. (A) Liver biopsies were obtained at the end of infusion and analyzed for triglyceride content. Each bar represents the mean \pm S.E.M. of five cows. ${ }^{*} P<0.05$. (B) Total RNA was obtained from liver biopsies taken at the end of infusion and analyzed by quantitative real-time PCR for expression of the indicated genes. For each gene, the expression of the indicated mRNA is relative to control, with each bar representing the mean \pm S.E.M. of five cows. not alter plasma free fatty acids (Table 2), ruling out a secondary effect through reduced lipid mobilization from adipose tissue. Overall, these data suggest that the reduction of plasma leptin around parturition exacerbates hepatic lipid accumulation in EL.

\section{Effect of increased plasma leptin on plasma thyroid hormones}

Energy-deficient animals, including dairy cows in EL (Table 1), rely on a depressed hypothalamicpituitary-thyroid axis to reduce energy consumption in tissues such as skeletal muscle (Mullur et al. 2014, Rosenbaum \& Leibel 2014). Consistent with leptin dependence of this axis in EL, cows infused with hLeptin experienced increases of $\sim 45 \%$ in the plasma concentrations of both $\mathrm{T}_{4}$ and $\mathrm{T}_{3}$ (Fig. $5 \mathrm{~A}, P<0.01$ ). In the case of plasma $\mathrm{T}_{3}$, this stimulation led to a near complete correction to concentrations prevailing during the energy sufficient state of LP (i.e., $1.32 \mathrm{ng} / \mathrm{mL}$ in EL cows treated with hLeptin vs $1.58 \mathrm{ng} / \mathrm{mL}$ in LP), whereas plasma levels remained depressed in Control cows $(0.91 \mathrm{ng} / \mathrm{mL})$; similar observations were made for plasma $\mathrm{T}_{4}$. Consistent with promotion of metabolic rate by thyroid hormones, the hLeptin-treated cows lost more weight than Control cows during the infusion period $(24 \pm 1.7$ vs $18 \pm 1.7 \mathrm{~kg}, P<0.02)$. By contrast, levels of plasma cortisol, which remained unchanged between LP and EL, were unaffected by the hLeptin infusion (Tables 1 and 2). These data implicate plasma

Published by Bioscientifica Ltd. 
A
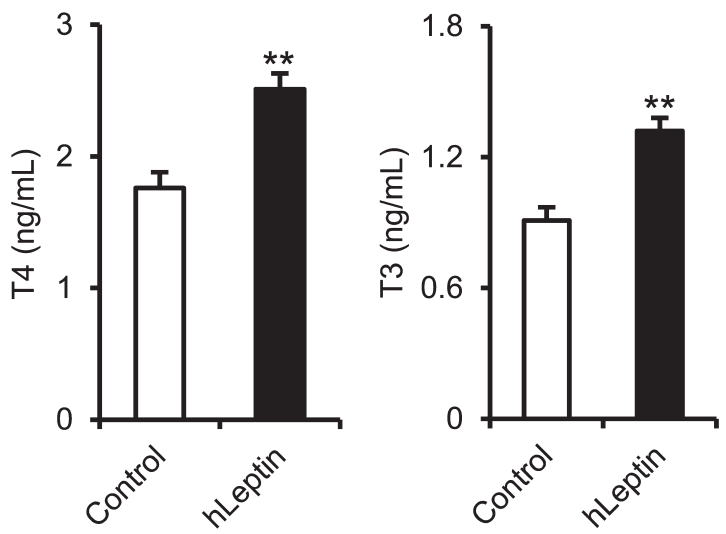

B

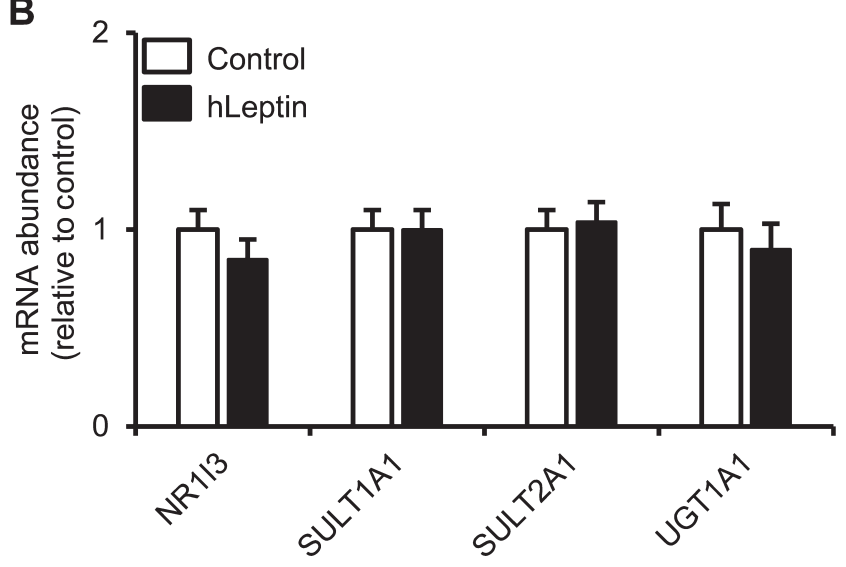

Figure $\mathbf{5}$

Effect of leptin infusion in early lactation on the plasma concentration of thyroid hormones. Dairy cows received a constant intravenous infusion of either saline (Control) or human leptin (hLeptin) starting on day 8 of lactation and lasting for 96 consecutive hours. (A) Plasma samples were obtained over the last $8 \mathrm{~h}$ of the infusion period and analyzed for the concentration of $T_{4}$ and $T_{3}$. For each hormone, each bar represents the mean \pm S.E.M. of five cows. ${ }^{*} P<0.01$. (B) Total RNA was obtained from liver biopsies taken at the end of infusion and analyzed by quantitative real-time PCR for expression of the indicated genes. For each gene, the expression of the indicated mRNA is relative to control, with each bar representing the mean \pm S.E.M. of five cows.

leptin as a determinant of plasma thyroid hormone levels and energy conservation in EL dairy cows.

Increased removal of thyroid hormones through hepatic sulfotransferases and glucuronidases contributes to their reduced concentrations in fasted rodents (Maglich et al. 2004, Vella et al. 2011). The hLeptin infusion, however, had no effect on the hepatic expression of the constitutive androstane receptor NR1I3 or its target sulfotransferase and glucuronidase genes SULT1A1, SULT2A1, and UGT1A1 (Fig. 5B). Accordingly, the positive effects of hLeptin on plasma thyroid hormones in early lactating dairy cows are unlikely to involve reduced hepatic removal.

\section{Effect of increased plasma leptin on secretion of GH and LH}

In dairy cows, the energy insufficiency of EL increases plasma GH and has the opposite effect on pulsatile LH secretion (Butler 2000, Boisclair et al. 2006). To determine whether exogenous leptin can reverse these effects, blood samples were obtained every $10 \mathrm{~min}$ over an 8 -h period on the last day of infusion. hLeptin infusion increased rather than decreased the average plasma GH concentration (Table 2, $P<0.04$ ), an effect that occurred without measurable differences in either GH pulse frequency or amplitude (Fig. 6) and in the absence of any increase in plasma IGF1 (Table 2). The hLeptin infusion was without effects on the average plasma LH concentration or other secretory variables (Table 2 and Fig. 7). These data do not support a causal role for the periparturient reduction of plasma leptin in increasing GH secretion or in suppressing LH secretion in early lactating dairy cows.

\section{Discussion}

In the modern dairy cow, milk production increases within days of parturition to near maximum levels. As a consequence, the mammary gland consumes as much energy on day 4 of lactation as the sum of all other maternal tissues and 4 times as much energy as the gravid uterus in LP (Bell 1995). The mammary demand for glucose is similarly extensive, with $85 \%$ of the whole animal supply devoted to lactose synthesis (Bell 1995). These nutritional challenges are compounded by the inability of dairy cows, unlike rodents, to increase voluntary feed intake in proportion to milk yield in EL (Bell 1995, Johnson et al. 2001, Vernon et al. 2002). The consequent energy insufficiency causes a reduction in leptin production even before significant depletion of fat depots occurs (Block et al. 2001, Reist et al. 2003, Janovick et al. 2011). We now provide evidence that this reduction in plasma leptin contributes to the adaptive metabolism of the early lactating dairy cow.

Virtually, all in vivo studies of leptin actions in ruminants have involved intracerebroventricular (ICV) administration (Henry et al. 1999, Morrison et al. 2001, Miller et al. 2002, Foskolos et al. 2015). Although these studies provide unambiguous evidence of leptin actions in ruminants, including anorexic actions,

Published by Bioscientifica Ltd 

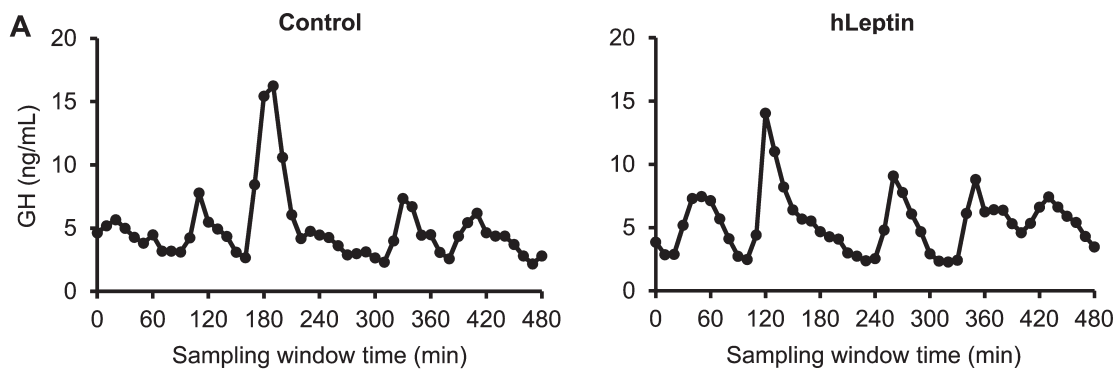

\section{Figure 6}

Effect of leptin infusion in early lactation on the profile of plasma GH. Dairy cows received a constant intravenous infusion of either saline
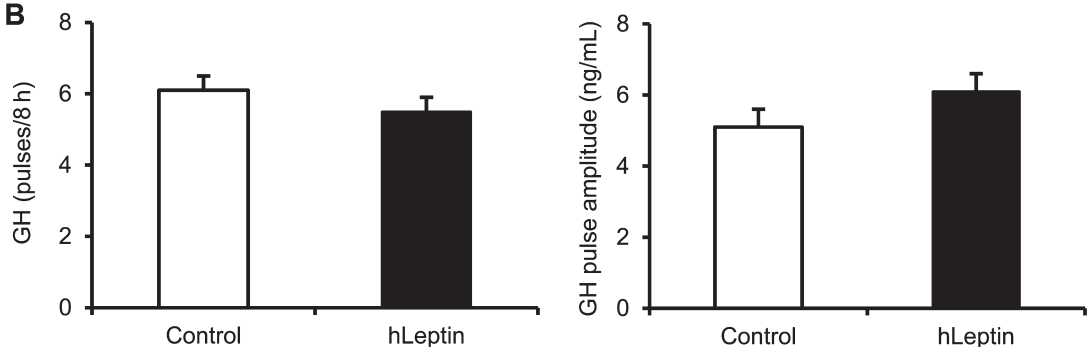
(Control) or hLeptin starting on day 8 of lactation and lasting for 96 consecutive hours. (A) Plasma samples were obtained every $10 \mathrm{~min}$ over the last $8 \mathrm{~h}$ of the infusion period and analyzed for the concentration of $\mathrm{GH}$. A representative cow is shown for each treatment. (B) The number of GH pulses and their amplitude were quantified as described in the "Materials and methods" section. Bars in each graph represent the mean \pm S.E.M. of five cows.

they have two significant limitations. First, none of these studies were conducted in lactating animals. Second, as recently discussed (Foskolos et al. 2015), these studies exposed neuronal centers to supraphysiological leptin concentrations and, therefore, provided little insight into the consequences of normal variation in plasma leptin. As an alternative, we countered the periparturient leptin reduction by infusing hLeptin into the vascular compartment. This approach produced steady-state plasma levels of $14 \mathrm{ng} / \mathrm{mL}$ for hLeptin, which, after correcting for its activity in the luciferase bioassay, raised the total effective leptin concentration to approximately $8 \mathrm{ng} / \mathrm{mL}$ (i.e., $14 \mathrm{ng} / \mathrm{mL}$ of human leptin $\times 38 \%+2.6 \mathrm{ng} / \mathrm{mL}$ of bovine leptin), well within the range of concentrations reported in late pregnant dairy cows (Block et al. 2001, Janovick et al. 2011, Reist et al. 2003). This elevation did not cause a significant reduction in energy intake at any time during the infusion period and had no impact on the milk energy output. One interpretation of these data is that voluntary feed intake becomes unresponsive to variation in plasma leptin during the energy deficit of EL, an idea supported by the failure of ICV leptin to reduce feed intake in severely feed-restricted sheep (Henry et al. 2001, Morrison et al. 2001). If leptin resistance exists in early lactating dairy cows, reduced plasma leptin may not lead to higher voluntary feed intake.
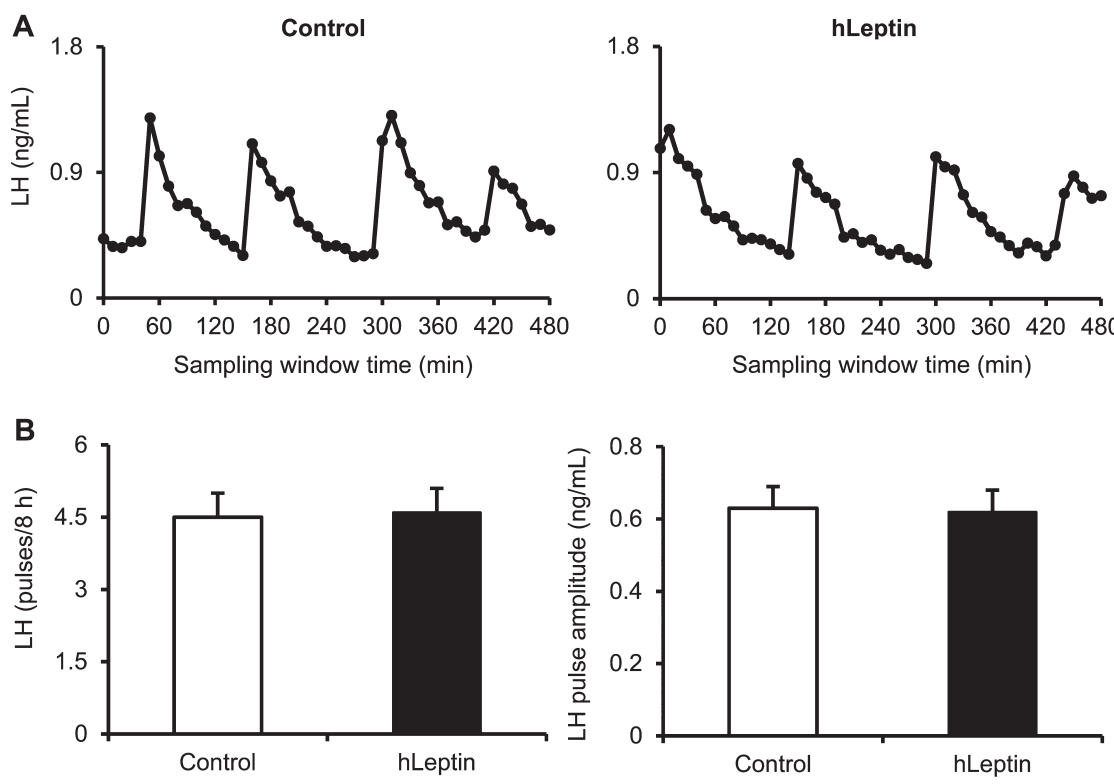

Figure 7

Effect of leptin infusion in early lactation on the profile of plasma LH. Dairy cows received a constant intravenous infusion of either saline (Control) or hLeptin starting on day 8 of lactation and lasting for 96 consecutive hours. (A) Plasma samples were obtained every $10 \mathrm{~min}$ over the last $8 \mathrm{~h}$ of the infusion period and analyzed for the concentration of $\mathrm{LH}$. A representative cow is shown for each treatment. (B) The number of LH pulses and their amplitude were quantified as described in the "Materials and methods" section. Bars in each graph represent the mean \pm S.E.M. of five cows. 
Our results illustrate the dynamic changes in glucose and lipid utilization during the transition from LP to EL and provide evidence for leptin regulation of these adaptations. With respect to glucose, low plasma insulin in EL combines with insulin resistance to limit glucose use by nonmammary tissue, safeguarding the available supply for lactose synthesis (Bell 1995, Boisclair et al. 2006). Correcting the leptin deficit of EL increased insulin-mediated glucose disposal and led to a more precarious glucose economy, as reflected by reduced plasma glucose and liver glycogen. We considered some of the mechanisms invoked to explain the positive actions of leptin on insulin action and glucose disposal. First, we asked whether leptin stimulated liver-derived IGFBP2, a protein reported to alleviate insulin resistance in the leptin-deficient ob/ob mice (Hedbacker et al. 2010). Second, we examined whether leptin repressed GH secretion. This second possibility was of interest because GH secretion is increased in early lactating dairy cows and antagonizes insulin-mediated glucose disposal (Sechen et al. 1990, Block et al. 2001, Rhoads et al. 2004). Moreover, ICV leptin prevented the increased GH secretion seen in pair-fed intact rams and in fasted adult ewes (Blache et al. 2000, Henry et al. 2004). However, neither mechanism explained the effect of leptin on the glucose economy as the hLeptin infusion failed to increase liver IGFBP2 expression and increased rather than decreased plasma GH concentration. The more precarious glucose economy with hLeptin treatment could also reflect the effects that could not be measured, including increased glucose uptake in skeletal muscle following activation of the autonomic nervous system (Minokoshi et al. 2002) and leptin stimulation of immune cell activity and associated glucose utilization (Palsson-McDermott \& O'Neill 2013, Naylor \& Petri 2016). Irrespective of the mechanism involved, however, our data point to a reduction in plasma leptin as one of the signals promoting glucose conservation during the transition from LP to EL.

Liver steatosis is a common feature of leptin-deficient rodents and was specifically attributed to reduced lipid oxidation by pair-feeding these animals to wild-type controls (Cohen et al. 2002, Prieur et al. 2008). Leptin therapy of these animals corrected the oxidative defect and the associated steatosis through repression of the hepatic fatty acid desaturase SCD1 (Cohen et al. 2002). The nature of liver steatosis differs in early lactating dairy cows, in that it is caused by excessive uptake of circulating free fatty acids, arising secondarily to their accelerated mobilization from adipose tissue (Drackley et al. 2001). Leptin remained effective in combating steatosis in these animals, reducing liver lipids by $28 \%$ over a mere 4 days of treatment. However, we found no evidence that hLeptin altered the hepatic expression of $S C D$, the bovine of ortholog of $S C D 1$, or of any other genes involved in the uptake, oxidation, or export of free fatty acids, suggesting a posttranscriptional effect. In this context, lipophagy has been recently implicated in the liver in the delivery of fatty acids from lipid droplets to the oxidative machinery (Singh et al. 2009). Lipophagy is not only engaged posttranslationally but also dependent on adequate thyroid hormone signaling (Singh et al. 2009, Sinha et al . 2012). Future work is needed to determine whether the anti-steatotic effects of hLeptin in early lactating dairy cows represent the activation of lipophagy in response to increased plasma thyroid hormones.

Circulating thyroid hormones are also known as rheostat of basal metabolism, particularly in cardiac and skeletal muscles (Lebon et al. 2001, Mullur et al. 2014). Accordingly, the reduction in circulating thyroid hormones in early lactating dairy cows has been viewed as an energy sparing mechanism (Vernon et al. 2002). This view is supported by increased energy expenditure and excessive weight loss in cows treated with exogenous thyroid hormones (Thomas 1953, Knight et al. 2004). The hLeptin infusion partially corrected the thyroid hormone deficit and exacerbated the loss of body weight without impacting milk production, suggesting an increase in a nonmammary component of energy expenditure. Our data resemble those obtained in humans sustaining a $10 \%$ reduction in body weight (Rosenbaum et al. 2005). These individuals experience reduced concentrations of thyroid hormones and energy expenditure and correction of both defects when treated peripherally with a low dose of leptin (Rosenbaum et al. 2005, Rosenbaum \& Leibel 2014). Interestingly, skeletal muscle was identified as the effector tissue for the opposing effects of weight loss and leptin on energy expenditure (Baldwin et al. 2011). Overall, our data implicate plasma leptin as a major determinant of circulating thyroid hormones and energy sparing in transition dairy cows.

The modulation of circulating thyroid hormones by leptin in rodents is the sum of reciprocal effects on production and removal. On the production side, leptin activates hypophysiotropic thyrotrophin-releasing hormone (TRH) neurons directly via its receptor, as well as indirectly by modulating the production of the neuropeptides $\alpha$-melanocyte-stimulating hormone $(\alpha-\mathrm{MSH})$ and neuropeptide Y (NPY) in the arcuate nucleus (Fekete \& Lechan 2014). Similar actions appear possible in dairy cows as we have recently showed that ICV infusion

Published by Bioscientifica Ltd. 
of a leptin antagonist reduced plasma thyroid hormone in the sheep (Foskolos et al. 2015), a closely related ruminant, whereas ICV infusion of an $\alpha$-MSH analog had the opposite effect (RA Ehrhardt and YR Boisclair, unpublished observations). With respect to removal, the liver contributes to the reduction of circulating thyroid hormones in fasted rodents through an increased expression of sulfotransferases and glucuronidases (Maglich et al. 2004, Vella et al. 2011, de Vries et al. 2014). In our study, however, we found no evidence that the positive effects of hLeptin on plasma thyroid hormones involve repression of liver sulfotransferases or glucuronidases.

Early lactating dairy cows often suffer from delayed or failed first ovulation and decreased fertility (Butler 2000). These defects have been attributed in part to the suppression of pulsatile LH secretion by the coexisting energy deficit. Given the negative association between plasma leptin and energy balance, hypoleptinemia in EL has been viewed as a candidate mediator of this effect. This is supported by positive associations among plasma leptin, LH pulsatility, and the time to first estrus in early lactating dairy cows (Kadokawa et al. 2000, Liefers et al. 2003), and by functional data showing leptin rescue of LH pulsatility in undernourished rams, ewes, and beef cows (Nagatani et al. 2000, Henry et al. 2001, Amstalden et al. 2002). These functional data, however, were obtained in gonadectomized animals with amplified sensitivity of the gonadotrophin-releasing hormone $(\mathrm{GnRH})$ pulse generator to the repressive effects of energy insufficiency. As shown by our results, energy-deficient, early lactating dairy cows retain significant LH pulsatility, and this is unaltered by infusion of hLeptin.

In summary, we show that some of the metabolic adaptations of EL (i.e., reduced insulin-mediated glucose disposal, reduced plasma thyroid hormones, and hepatic lipid accumulation) are attenuated by restoration of plasma leptin to levels prevailing in LP. These data suggest that the reduction of plasma leptin between LP and EL is one of the signals contributing to these adaptations in the modern dairy cow. Future work is needed in dairy cows to determine whether leptin regulation of thyroid hormone production underpins its effects on liver lipids and whether skeletal muscle is the main effector tissue of leptin actions on insulin response and energy sparing.

\section{Supplementary data}

This is linked to the online version of the paper at http://dx.doi.org/10.1530/ JOE-16-0031.

\section{Declaration of interest}

The authors declare that there is no conflict of interest that could be perceived as prejudicing the impartiality of the research reported.

\section{Funding}

This material is based upon the work that is supported by the National Research Initiative, the US Department of Agriculture under the award number US2003-35203-12832 and by the National Institute of Food and Agriculture, the US Department of Agriculture (Hatch/Multistate project under 1000962).

\section{Acknowledgment}

We thank Drs D Hancock and J Kube (Elanco Animal Health) for providing human leptin, Dr J E Darnell (Rockefeller University) for providing the luciferase plasmid p4xM67-TK-Luc, and Ramona Ehrhardt and Susanne Pelton for analyzing plasma metabolites and hormones.

\section{References}

Amstalden M, Garcia MR, Stanko RL, Nizielski SE, Morrison CD, Keisler DH \& Williams GL 2002 Central infusion of recombinant ovine leptin normalizes plasma insulin and stimulates a novel hypersecretion of luteinizing hormone after short-term fasting in mature beef cows. Biology of Reproduction 66 1555-1561. (doi:10.1095/biolreprod66.5.1555)

Baldwin KM, Joanisse DR, Haddad F, Goldsmith RL, Gallagher D, Pavlovich KH, Shamoon EL, Leibel RL \& Rosenbaum M 2011 Effects of weight loss and leptin on skeletal muscle in human subjects. American Journal of Physiology: Regulatory, Integrative and Comparative Physiology 301 R1259-R1266. (doi:10.1152/ajpregu.00397.2011)

Bauman DE \& Vernon RG 1993 Effects of exogenous bovine somatotropin on lactation. Annual Review of Nutrition 13 437-461. (doi:10.1146/annurev.nu.13.070193.002253)

Bell AW 1995 Regulation of organic nutrient metabolism during transition from late pregnancy to early lactation. Journal of Animal Science 73 2804-2819.

Besser D, Bromberg JF, Darnell JE Jr \& Hanafusa H 1999 A single amino acid substitution in the v-Eyk intracellular domain results in activation of Stat3 and enhances cellular transformation. Molecular and Cellular Biology 19 1401-1409. (doi:10.1128/MCB.19.2.1401)

Blache D, Celi P, Blackberrv MA, Dynes RA \& Martin GB 2000 Decrease in voluntary feed intake and pulsatile luteinizing hormone secretion after intracerebroventricular infusion of recombinant bovine leptin in mature male sheep. Reproduction, Fertility, and Development 12 373-381. (doi:10.1071/RD00102)

Block SS, Butler WR, Ehrhardt RA, Bell AW, Van Amburgh ME \& Boisclair YR 2001 Decreased concentration of plasma leptin in periparturient dairy cows is caused by negative energy balance. Journal of Endocrinology 171 339-348. (doi:10.1677/joe.0.1710339)

Boisclair YR, Brown AL, Casola S \& Rechler MM 1993 Three clustered Sp1 sites are required for efficient transcription of the TATA-less promoter of the gene for insulin-like growth factor-binding protein-2 from the rat. Journal of Biological Chemistry 268 24892-24901.

Boisclair YR, Seto D, Hsieh S, Hurst KR \& Ooi GT 1996 Organization and chromosomal localization of the gene encoding the mouse acid labile subunit of the insulin-like growth factor binding complex. PNAS 93 10028-10033. (doi:10.1073/pnas.93.19.10028)

Boisclair YR, Wesolowski SR, Kim JW \& Ehrhardt RA 2006 Roles of growth hormone and leptin in the periparturient dairy cow.

Published by Bioscientifica Ltd. 
In Proceedings of the Xth International Symposium on Ruminant Physiology, pp327-346. Eds K Sejrsen, T Hvelplund \& MO Nielsen. Wageningen, The Netherlands: Wageningen Academic Publishers. (doi:10.3920/978-90-8686-566-6)

Butler WR 2000 Nutritional interactions with reproductive performance in dairy cattle. Animal Reproduction Science 60-61 449-457. (doi:10.1016/S0378-4320(00)00076-2)

Butler ST, Pelton SH \& Butler WR 2006 Energy balance, metabolic status, and the first postpartum ovarian follicle wave in cows administered propylene glycol. Journal of Dairy Science 89 2938-2951. (doi:10.3168/ jds.S0022-0302(06)72566-8)

Chinookoswong N, Wang J-L \& Shi Z-Q 1999 Leptin restores euglycemia and normalizes glucose turnover in insulin-deficient diabetes in the rat. Diabetes 48 1487-1492. (doi:10.2337/diabetes.48.7.1487)

Cohen P, Miyazaki M, Socci ND, Hagge-Greenberg A, Liedtke W, Soukas AA, Sharma R, Hudgins LC, Ntambi JM \& Friedman JM 2002 Role for stearoyl-CoA desaturase-1 in leptin-mediated weight loss. Science 297 240-243. (doi:10.1126/science.1071527)

de Vries EM, Eggels L, van Beeren HC, Ackermans MT, Kalsbeek A, Fliers E \& Boelen A 2014 Fasting-induced changes in hepatic thyroid hormone metabolism in male rats are independent of autonomic nervous input to the liver. Endocrinology 155 5033-5041. (doi:10.1210/en.2014-1608)

Drackley JK, Overton TR \& Douglas GN 2001 Adaptations of glucose and long-chain fatty acid metabolism in liver of dairy cows during the periparturient period. Journal of Dairy Science 84 E100-E112. (doi:10.3168/jds.S0022-0302(01)70204-4)

Ehrhardt RA, Slepetis RM, VanAmburgh ME, Siegal-Willot J, Bell AW \& Boisclair YR 2000 Development of a specific RIA to measure physiological changes of circulating leptin in cattle and sheep. Journal of Endocrinology 166 519-528. (doi:10.1677/joe.0.1660519)

Fekete C \& Lechan RM 2014 Central regulation of hypothalamicpituitary-thyroid axis under physiological and pathophysiological conditions. Endocrine Reviews 35 159-194. (doi:10.1210/er.2013-1087)

Foskolos A, Ehrhardt RA, Hileman SM, Gertler A \& Boisclair YR 2015 Insensitivity of well-conditioned mature sheep to central administration of a leptin receptor antagonist. Animal 11 1852-1858. (doi:10.1017/S1751731115001159)

Giesy SL, Yoon B, Currie WB, Kim JW \& Boisclair YR 2012 Adiponectin deficit during the precarious glucose economy of early lactation in dairy cows. Endocrinology 153 5834-5844. (doi:10.1210/ en.2012-1765)

Hedbacker K, Birsoy K, Wysocki RW, Asilmaz E, Ahima RS, Farooqi IS \& Friedman JM 2010 Antidiabetic effects of IGFBP2, a leptinregulated gene. Cell Metabolism 11 11-22. (doi:10.1016/ j.cmet.2009.11.007)

Henry BA, Goding JW, Alexander WS, Tilbrook AJ, Canny BJ, Dunshea F, Rao A, Mansell A \& Clarke IJ 1999 Central administration of leptin to ovariectomized ewes inhibits food intake without affecting the secretion of hormones from the pituitary gland: Evidence for a dissociation of effects on appetite and neuroendocrine function. Endocrinology 140 1175-1182. (doi:10.1210/endo.140.3.6604)

Henry BA, Goding JW, Tilbrook AJ, Dunshea FR \& Clarke IJ 2001 Intracerebroventricular infusion of leptin elevates the secretion of luteinising hormone without affecting food intake in long-term food-restricted sheep, but increases growth hormone irrespective of bodyweight. Journal of Endocrinology 168 67-77. (doi:10.1677/ joe.0.1680067)

Henry BA, Goding JW, Tilbrook AJ, Dunshea FR, Blache D \& Clarke IJ 2004 Leptin-mediated effects of undernutrition or fasting on luteinizing hormone and growth hormone secretion in ovariectomized ewes depend on the duration of metabolic perturbation. Journal of Neuroendocrinology 16 244-255. (doi:10.1111/ j.0953-8194.2004.01157.x

Janovick NA, Boisclair YR \& Drackley JK 2011 Prepartum dietary energy intake affects metabolism and health during the periparturient period in primiparous and multiparous Holstein cows. Journal of Dairy Science 94 1385-1400. (doi:10.3168/jds.2010-3303)

Johnson MS, Thomson SC \& Speakman JR 2001 Limits to sustained energy intake. I. Lactation in the laboratory mouse Mus musculus. Journal of Experimental Biology 204 1925-1935.

Kadokawa H, Blache D, Yamada Y \& Martin GB 2000 Relationships between changes in plasma concentrations of leptin before and after parturition and the timing of first post-partum ovulation in high-producing Holstein dairy cows. Reproduction, Fertility and Development 12 405-411. (doi:10.1071/RD01001)

Kamohara S, Burcelin R, Halaas JL, Friedman JM \& Charron MJ 1997 Acute stimulation of glucose metabolism in mice by leptin treatment. Nature 389 374-377. (doi:10.1038/38717)

Karsch FJ, Cummins JT, Thomas GB \& Clarke IJ 1987 Steroid feedback inhibition of pulsatile secretion of gonadotropin-releasing hormone in the ewe. Biology of Reproduction 36 1207-1218. (doi:10.1095/ biolreprod36.5.1207)

Knight CH, Alamer MA, Sorensen A, Nevison IM, Flint DJ \& Vernon RG 2004 Metabolic safety-margins do not differ between cows of high and low genetic merit for milk production. Journal of Dairy Research 71 141-153. (doi:10.1017/S0022029904000044)

Lebon V, Dufour S, Petersen KF, Ren J, Jucker BM, Slezak LA, Cline GW Rothman DL \& Shulman GI 2001 Effect of triiodothyronine on mitochondrial energy coupling in human skeletal muscle. Journal of Clinical Investigation 108 733-737. (doi:10.1172/ JCI200111775)

Leury BJ, Baumgard LH, Block SS, Segoale N, Ehrhardt RA, Rhoads RP, Bauman DE, Bell AW \& Boisclair YR 2003 Effect of insulin and growth hormone on plasma leptin in periparturient dairy cows. American Journal of Physiology: Regulatory, Integrative and Comparative Physiology 285 R1107-R1115.

Levin N, Nelson C, Gurney A, Vandlen R \& de Sauvage F 1996 Decreased food intake does not completely account for adiposity reduction after ob protein infusion. PNAS 93 1726-1730. (doi:10.1073/ pnas.93.4.1726)

Liefers SC, Veerkamp RF, Pas MF,Delavaud C, Chilliard Y \& van der Lende T 2003 Leptin concentrations in relation to energy balance, milk yield, intake, live weight, and estrus in dairy cows. Journal of Dairy Science 86 799-807. (doi:10.3168/jds.S00220302(03)73662-5)

Maglich JM, Watson J, McMillen PJ, Goodwin B, Willson TM \& Moore JT 2004 The nuclear receptor CAR is a regulator of thyroid hormone metabolism during caloric restriction. Journal of Biological Chemistry 279 19832-19838. (doi:10.1074/jbc.M313601200)

Miller DW, Findlay PA, Morrison MA, Raver N \& Adam CL 2002 Seasonal and dose-dependent effects of intracerebroventricular leptin on $\mathrm{lh}$ secretion and appetite in sheep. Journal of Endocrinology $\mathbf{1 7 5}$ 395-404. (doi:10.1677/joe.0.1750395)

Minokoshi Y, Kim YB, Peroni OD, Fryer LG, Muller C, Carling D \& Kahn BB 2002 Leptin stimulates fatty-acid oxidation by activating AMP-activated protein kinase. Nature 415 339-343. (doi:10.1038/415339a)

Morrison CD, Daniel JA, Holmberg BJ, Djiane J, Raver N, Gertler A \& Keisler DH 2001 Central infusion of leptin into well-fed and undernourished ewe lambs: effects on feed intake and serum concentrations of growth hormone and luteinizing hormone. Journal of Endocrinology 168 317-324. (doi:10.1677/joe.0.1680317)

Mullur R, Liu YY \& Brent GA 2014 Thyroid hormone regulation of metabolism. Physiological Reviews 94 355-382. (doi:10.1152/ physrev.00030.2013)

Nagatani S, Zeng Y, Keisler DH, Foster DL \& Jaffe CA 2000 Leptin regulates pulsatile luteinizing hormone and growth hormone secretion in the sheep. Endocrinology 141 3965-3975. (doi:10.1210/ endo.141.11.7762)

National Research Council 2001 Nutrient Requirements of Dairy Cattle, edn 7, Washington, DC, USA: National Academy Press. http://joe.endocrinology-journals.org

DOI: 10.1530/JOE-16-0031
C 2016 Society for Endocrinology Printed in Great Britain 
Naylor C \& Petri WA Jr 2016 Leptin regulation of immune responses. Trends in Molecular Medicine 22 88-98. (doi:10.1016/ j.molmed.2015.12.001)

Palsson-McDermott EM \& O'Neill LA 2013 The Warburg effect then and now: from cancer to inflammatory diseases. Bioessays 35 965-973. (doi:10.1002/bies.201300084)

Park HK \& Ahima RS 2015 Physiology of leptin: energy homeostasis, neuroendocrine function and metabolism. Metabolism 64 24-34. (doi:10.1016/j.metabol.2014.08.004)

Prentice AM \& Prentice A 1988 Energy costs of lactation. Annual Review of Nutrition 8 63-79. (doi:10.1146/annurev.nu.08.070188.000431)

Prieur X, Tung YC, Griffin JL, Farooqi IS, O'Rahilly S \& Coll AP 2008 Leptin regulates peripheral lipid metabolism primarily through central effects on food intake. Endocrinology 149 5432-5439. (doi:10.1210/en.2008-0498)

Reist M, Erdin D, von Euw D, Tschuemperlin K, Leuenberger H, Delavaud C, Chilliard Y, Hammon HM, Kuenzi N \& Blum JW 2003 Concentrate feeding strategy in lactating dairy cows: metabolic and endocrine changes with emphasis on leptin. Journal of Dairy Science 86 1690-1706. (doi:10.3168/jds.S0022-0302(03)73755-2)

Rhoads RP, Kim JW, Leury BJ, Baumgard LH, Segoale N, Frank SJ, Bauman DE \& Boisclair YR 2004 Insulin increases the abundance of the growth hormone receptor in liver and adipose tissue of periparturient dairy cows. Journal of Nutrition 134 1020-1027.

Rosenbaum M \& Leibel RL 201420 YEARS OF LEPTIN: Role of leptin in energy homeostasis in humans. Journal of Endocrinology $\mathbf{2 2 3}$ T83-T96. (doi:10.1530/JOE-14-0358)

Rosenbaum M, Goldsmith R, Bloomfield D, Magnano A, Weimer L, Heymsfield S, Gallagher D, Mayer L, Murphy E \& Leibel RL 2005 Low-dose leptin reverses skeletal muscle, autonomic, and neuroendocrine adaptations to maintenance of reduced weight.
Journal of Clinical Investigation 115 3579-3586. (doi:10.1172/ JCI25977)

Sechen SJ, Dunshea FR \& Bauman DE 1990 Somatotropin in lactating cows: effect on response to epinephrine and insulin. American Journal of Physiology 258 E582-E588.

Shipley RA \& Clark ER 1972 Tracer Methods for In Vivo Kinetics: Theory and Application. New York, NY, USA: Academic Press Inc.

Singh R, Kaushik S, Wang Y, Xiang Y, Novak I, Komatsu M, Tanaka K, Cuervo AM \& Czaja MJ 2009 Autophagy regulates lipid metabolism. Nature 458 1131-1135. (doi:10.1038/nature07976)

Sinha RA, You SH, Zhou J, Siddique MM, Bay BH, Zhu X, Privalsky ML, Cheng SY, Stevens RD, Summers SA, et al. 2012 Thyroid hormone stimulates hepatic lipid catabolism via activation of autophagy. Journal of Clinical Investigation 122 2428-2438. (doi:10.1172/ JCI60580)

Thomas JW 1953 The use of thyroprotein for milk production. In Hormone Relationships and Applications in the Production of Meats, Milk and Eggs, pp47-54. Ed JF Sykes. Washington, DC, USA: Agricultural Board, National Research Council.

Vella KR, Ramadoss P, Lam FS, Harris JC, Ye FD, Same PD, O'Neill NF, Maratos-Flier E \& Hollenberg AN 2011 NPY and MC4R signaling regulate thyroid hormone levels during fasting through both central and peripheral pathways. Cell Metabolism 14 780-790. (doi:10.1016/j. cmet.2011.10.009)

Vernon RG, Denis RG, Sorensen A \& Williams G 2002 Leptin and the adaptations of lactation in rodents and ruminants. Hormone and Metabolic Research 34 678-685. (doi:10.1055/s-2002-38258)

Wook Kim J, Rhoads RP, Block SS, Overton TR, Frank SJ \& Boisclair YR 2004 Dairy cows experience selective reduction of the hepatic growth hormone receptor during the periparturient period. Journal of Endocrinology 181 281-290. (doi:10.1677/joe.0.1810281)

Received in final form 18 January 2016

Accepted 3 March 2016

Accepted Preprint published online 7 March 2016
๑) 2016 Society for Endocrinology Printed in Great Britain 